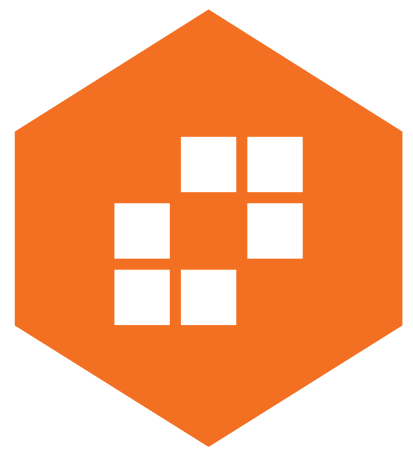

The International Journal of

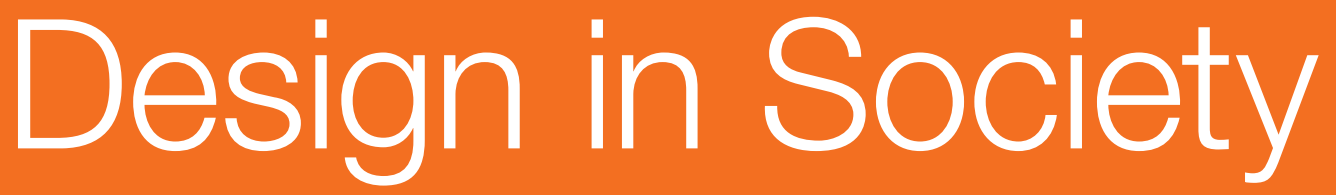

\title{
Designing Schools for Children with Impairments
}

The Powers of Architecture 


\section{EDITORS}

Lorenzo Imbesi, Sapienza University of Rome, Italy

Loredana Di Lucchio, University of Rome, Italy

ACTING DIRECTOR OF PUBLISHING

Jeremy Boehme, Common Ground Research Networks, USA

\section{MANAGING EDITOR}

Helen Repp, Common Ground Research Networks, USA

\section{ADVISORY BOARD}

The Design Principles and Practices Research Network recognizes the contribution of many in the evolution of the Research Network. The principal role of the Advisory Board has been, and is, to drive the overall intellectual direction of the Research Network.

A full list of members can be found at

https://designprinciplesandpractices.com/about/advisory-board.

\section{PEER REVIEW}

Articles published in The International Journal of Design in Society are peer reviewed using a two-way anonymous peer review model. Reviewers are active participants of the Design Principles and Practices Research Network or a thematically related Research Network. The publisher, editors, reviewers, and authors all agree upon the following standards of expected ethical behavior, which are based on the Committee on Publication Ethics (COPE) Core Practices. More information can be found at:

https://designprinciplesandpractices.com/journals/model.

\section{ARTICLE SUBMISSION}

The International Journal of Design in Society

publishes quarterly (March, June, September, December).

To find out more about the submission process, please visit

https://designprinciplesandpractices.com/journals/call-for-papers.

\section{THE INTERNATIONAL JOURNAL}

\section{OF DESIGN IN SOCIETY}

http://designprinciplesandpractices.com

ISSN: 2325-1328 (Print)

ISSN: 2325-1360 (Online)

https://doi.org/10.18848/2325-1328/CGP (Journal)

First published by Common Ground Research Networks in 2019

University of Illinois Research Park

2001 South First Street, Suite 202

Champaign, IL 61820 USA

$\mathrm{Ph}:+1-217-328-0405$

http://cgnetworks.org

The International Journal of Design in Society

is a peer-reviewed, scholarly journal

\section{COPYRIGHT}

(C) 2019 (individual papers), the author(s)

(C) 2019 (selection and editorial matter),

Common Ground Research Networks

All rights reserved. Apart from fair dealing for the purposes of study, research, criticism, or review, as permitted under the applicable copyright legislation, no part of this work may be reproduced by any process without written permission from the publisher. For permissions and other inquiries, please contact cgscholar.com/cg_support.

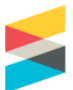

\section{Crossref}

Common Ground Research Networks, a member of Crossref

\section{ABSTRACTING AND INDEXING}

For a full list of databases in which this journal is indexed, please visit https://designprinciplesandpractices.com/journals/collection.

\section{RESEARCH NETWORK MEMBERSHIP}

Authors in The International Journal of Design in Society are members of the Design Principles and Practices Journal Collection or a thematically related Research Network. Members receive access to journal content. To find out more, visit

https://designprinciplesandpractices.com/about/become-a-member.

\section{SUBSCRIPTIONS}

The International Journal of Design in Society is available in electronic and print formats. Subscribe to gain access to content from the current year and the entire backlist.

Contact us at cgscholar.com/cg support.

\section{ORDERING}

Single articles and issues are available from the journal bookstore at https://cgscholar.com/bookstore.

\section{HYBRID OPEN ACCESS}

The International Journal of Design in Society

is Hybrid Open Access, meaning authors can choose to make their articles open access. This allows their work to reach an even wider audience, broadening the dissemination of their research.

To find out more, please visit

https://designprinciplesandpractices.com/journals/hybrid-open-access.

\section{DISCLAIMER}

The authors, editors, and publisher will not accept any legal responsibility for any errors or omissions that may have been made in this publication. The publisher makes no warranty, express or implied, with respect to the material contained herein. 


\title{
Designing Schools for Children with Impairments: The Powers of Architecture
}

\author{
Jacqueline McIntosh, ${ }^{1}$ Victoria University of Wellington, New Zealand \\ Bruno Marques, Victoria University of Wellington, New Zealand \\ Joelle Lim, Victoria University of Wellington, New Zealand
}

\begin{abstract}
Education is an important foundation of society yet children with impairments have limited opportunities for participation in school activities. There is a lack of functionality in the design of school spaces and outdoor play areas for children with impairments, arguably as there are insufficient performance guidelines that target the body condition of children with impairments. Architectural barriers that prevent a child's participation in school can decrease their quality of life, often resulting in the further deterioration of their health. This research explores existing knowledge across disciplines aimed at promoting and facilitating impaired children's physical and mental resilience and well-being in a school environment. The research method involves systematic evaluation of the current school design knowledge surrounding the creation of learning environments that target children with impairments and proposes a set of performance-based design criteria. It finds that there is a lack of health research examining the usefulness of classroom and play spaces for children with impairments, which prohibit an ideal learning environment for children with multiple impairments. In addition, it finds a demand for greater integration of outdoor play with education, which in turn can make participation within schools more enjoyable.
\end{abstract}

Keywords: Children with Impairments, School Participation, Impairments, School Design, Play

\section{Introduction}

G lobally, the population of children with impairments is 93 million and international statistics indicate that one in every ten children have a disability (UNICEF, 2013). Children with impairments are one of the most marginalized and excluded groups of society (UNICEF 2013) and within the population of primary school age children with impairments, only 10 percent are in school (WHO 2011). Of these, only 5 percent have completed their primary education (WHO 2011). The lack of participation in primary school has been associated with poor health and wellbeing (Law 2002) for both the child and their family. Within rehabilitation treatment programs, participation is considered to be one of the more important outcomes for parents and children (Bult et al. 2011). Progressive rehabilitation has been shown to improve the individual's independence, well-being, and reduce the progressive nature of some impairments (Marques et al. 2019; Kershaw et al. 2017). However, the lack of facilities and services and the lack of participation in schools reduce the opportunities for education and "academic opportunities and psychosocial development" (Sorani-Villanueva et al. 2014, 61). Studies have found that the most common barriers to participation in primary school education are the physical accessibility of the environment and a comprehensive lack of support (Anaby et al. 2013).

A child's physical environment is closely related to their emotional health (National Scientific Council on Developing Children 2011). However, the needs of children with impairments generally are not addressed in the school system. School design criteria for children with impairments are very limited and the necessary furnishings and features to cope with their impairments are often lacking. Addressing the need of children with impairments is often dealt with through design guides written specifically for the design of special-needs schools. Learning-

\footnotetext{
${ }^{1}$ Corresponding Author: Jacqueline McIntosh, School of Architecture, Faculty of Architecture and Design, Victoria University of Wellington, PO Box 600, Wellington, 6140, New Zealand. email: Jacqueline.mcintosh@vuw.ac.nz
}

The International Journal of Design in Society

Volume 13, Issue 3, 2019, https://designprinciplesandpractices.com

(C) Common Ground Research Networks, Jacqueline McIntosh, Bruno Marques, Joelle Lim,

All Rights Reserved. Permissions: cgscholar.com/cg_support

ISSN: 2325-1328 (Print), ISSN: 2325-1360 (Online)

https://doi.org/10.18848/2325-1328/CGP/v13i03/17-29 (Article) 
environment design principles for children with impairments generally focus on access; space; sensory-awareness; flexibility and adaptability; safety and security; and sustainability (AbdelMaksoud 2016). More typically, design environments are generally worlds "without disabled people or where gender is little more than the perpetuation of patriarchal relations...a world where bodies are reduced to an asexual status and where architecture and design was conceived...to a highly specialized system with a set of prescribed technical goals" (Imrie and Hall 2003, 12).

It has been argued that impairment becomes disability when the environment prevents the impaired child from doing what an abled-body child would do. However, disability is often viewed as "a disease that requires treatment and in this sense, the disability (as impairment) is seen as the problem to be overcome rather than a social or environmental barrier" (Imrie and Kumar 1998, 359). Mainstream schools today seek to address inclusion through the provision of collaborative or workshop-based learning spaces such as modern learning environments. Within public buildings, architectural element consideration such as "pavements tend to be littered with obstacles while most public building provide few design features to permit disabled people ease of access...color contrasts and tactile are poorly designed and/or often non-existent" (Imrie and Kumar 1998, 357). Built environments are not equipped and suited for people with impairments and buildings only represent adult able-bodied values, "like steps and restrictions on entry to buildings", which could serve to "exclude of produce discomfort or nuisance" (Imrie and Kumar 1998, 359). The outcomes of these strategies hamper access to education, often resulting in children staying at home without proper opportunities to access education or physical and psychosocial domains (Mah et al. 2008).

This research investigates many different architectural and therapeutic strategies toward improving participation for children with impairments. The project identifies design and motivational strategies within learning spaces that promote both physical and mental wellbeing within outdoor learning environments. Using a multidisciplinary lens, the results have been assessed and systematically evaluated on the effectiveness of learning for an impaired child. Through this, it was possible to identify appropriate design parameters for the development of future outdoor learning environments that can be adequately equipped to facilitate children-withimpairments' education.

\section{Methods}

A comprehensive search was performed using Google Scholar and electronic databases as well as landmark book publications. Search terms such as "child" or "children" were combined with "impairments," "disability," "participation," "school," "rehabilitation," and "play" to identify beneficial design criteria for children with impairment. Only peer-reviewed publications were chosen for the subsequent selection of articles. Exclusion criteria were: 1) studies were limited to children under 5 or youth above the age of 12 years old; 2) studies only aimed at children with mobility, visual, hearing and intellectual impairments; 3) studies published in other than the English language; 4) intervention studies; 5) review papers; and 6) theses.

After excluding studies on the search across the databases, 200 studies were evaluated based on title and abstract. Following this first selection and based on the exclusion criteria, ninety studies remained. A further fifty-eight studies were excluded based on the content of their full text, resulting in sixteen studies remaining for this review. The articles were critically evaluated by conducting a strengths and weaknesses analysis of the study design. As causal relationships between therapeutic environments and human health are difficult to establish, this critical literature review covered studies that focused on association rather than causation. The literature reviewed revealed a number of themes and relationships that relate to school design for children with impairments. These themes and relationships were used to construct a conceptual framework based on four thematic key findings. This was achieved by organizing the themes and relationships, in the conceptual framework, according to associations that were empirically 
evaluated by published studies. To extend the understanding of inclusive schools, the theoretical literature was complemented with a case study review to examine how the issues raised in the literature review were addressed in practice.

\section{Findings}

Studies highlighted the significance of outdoor learning spaces and the importance of play that could promote physical activity. The thematic analysis revealed four key learning environment criteria: playful outdoor learning environments; sensory integrated activities; community engagement; and fostering stress recovery strategies for occupants that could improve participation for children with impairments. These have been summarized in Table 1 .

Table 1: Thematic Analysis of the Key Literature

\begin{tabular}{|c|c|}
\hline fied Theme & Reference Sources \\
\hline $\begin{array}{l}\text { learning } \\
\text { hent: } \\
\text { ig } \\
\text { s self- } \\
\text { play }\end{array}$ & $\begin{array}{l}\text { Anaby et al. 2013. "The Effect of the Environment on Participation of } \\
\text { Children and Youth with Disabilities: A Scoping Review." } \\
\text { Barbour. 1999. "The Impact of Playground Design on the Play } \\
\text { Behaviors of Children with Differing Levels of Physical } \\
\text { Competence." "The Importance of Outdoor Play for Young } \\
\text { Bento and Dias. 2017. "The } \\
\text { Children's Healthy Development." } \\
\text { Ginsburg. 2007. "The Importance of Play in Promoting Healthy Child } \\
\text { Development and Maintaining Strong Parent-Child Bonds." } \\
\text { Gray. 2011. "The Decline of Play and the Rise of Psychopathology in } \\
\text { Children and Adolescents." } \\
\text { Hendricks. 2011. Designing for Play } \\
\text { Scott. 2010. Architecture for Children. }\end{array}$ \\
\hline $\begin{array}{l}\text { Sens } \\
\text { play }\end{array}$ & $\begin{array}{l}\text { Ayres and Robbins. 2005. Sensory Integration and the Child: } \\
\text { Understanding Hidden Sensory Challenges. } \\
\text { Case-Smith and Bryan. 1999. "The Effects of Occupational Therapy } \\
\text { with Sensory Integration Emphasis on Preschool-Age } \\
\text { Children with Autism." }\end{array}$ \\
\hline $\begin{array}{l}\text { munity use: } \\
\text { iency with } \\
\text { ing } \\
\text { onment }\end{array}$ & $\begin{array}{l}\text { Abi Daoud et al. 2004. "Depression in Parents of Children with } \\
\text { Duchenne Muscular Dystrophy." } \\
\text { Bult et al. 2011. "What Influences Participation in Leisure Activities } \\
\text { of Children and Youth with Physical Disabilities? A } \\
\text { Systematic Review." } \\
\text { Kaplan and Kaplan. 1989. The Experience of Nature: A } \\
\text { Psychological Perspective. } \\
\text { Murphy et al. 2007. "The Health of Caregivers for Children with } \\
\text { Disabilities: Caregiver Perspectives." } \\
\text { Murphy and Carbone. 2008. Promoting the Participation of Children } \\
\text { with Disabilities in Sports, Recreation and Physical } \\
\text { Activities. }\end{array}$ \\
\hline $\begin{array}{l}\text { Reducing stress: } \\
\text { architectural } \\
\text { strategies }\end{array}$ & $\begin{array}{l}\text { Evans. 1984. Environmental Stress. } \\
\text { Evans and McCoy. 1998. When Buildings Don't Work: The Role of } \\
\text { Architecture in Human Health. } \\
\text { Hartig and Evans. 1993. Psychological Foundations of Nature } \\
\text { Experience. }\end{array}$ \\
\hline
\end{tabular}


The importance of play was a key theme in the readings and has been widely recognized as a right of every child. "Play is important as it develops cognitive, physical, social and emotional well-being in children" (National Scientific Council on Developing Children 2011,4) and is cherished part of childhood (Ginsburg 2007). However, many parents and teachers disregard play as important for young children (Rothlein and Brett 1987). Over the last half century, opportunities for free play have been significantly reduced due to "a hurried lifestyle, changes in family structure, and increased attention to academic and enrichment activities at the expense of recess or free child-centered play" (Ginsburg 2007, 182; Gray 2011). As a result of reduced play, psychopathology in children and adolescents such as anxiety, depression, feelings of helplessness and narcissism have exhibited a corresponding increase (Gray 2011), and research finds increased suicidal thoughts and attempts in children and adolescents (Gray 2011). Although some children thrive in highly scheduled environments, often these environments are accompanied with a reduced time for physical activity and a reduction in the amount of playtime. As such, schools have been held responsible for supporting sedentary lifestyles that can be ill-suited to unearthing the learning potential and academic abilities in children with impairments.

Often, classroom spaces are designed to promote socializing and collaboration; however, studies found that limited attention was directed toward the accessibility of the learning environments, such as sufficient circulation, a lack of ramps, elevators, and parking space for wheelchairs, as well as access to public transportation (Anaby et al. 2013). The lack of adequate supported areas to store special equipment and access were identified as barriers of children with impairments.

\section{Outdoor Learning Environment: Facilitating Children's Self-directed Play}

Play allows children to create and explore a world they can master, conquering their fears while practicing adult roles, sometimes in conjunction with other children or adult caregivers. As they master their world, play helps children develop new competencies that lead to enhanced confidence and the resiliency they will need to face future challenges. (Ginsburg 2007, 183)

Children with impairments require play as a form of physical and mental rehabilitation to improve their independence that could extend their life expectancy (Ginsburg 2007). Play activities are important to a child's development, contributing to the cognitive, physical, social, and emotional well-being (Ginsburg 2007) and promoting the necessary conditions for children to thrive and learn (Bento and Dias 2017). Through play, children "use their creativity while developing their imagination, dexterity, and physical, cognitive, and emotional strength" (Ginsburg 2007, 183). Studies found that undirected play also allows children to learn how to participate and work with groups, sharing, negotiate, resolve conflict, and gain self-advocacy skills. As play becomes child-driven, evidence shows that the child begins to practice their own decision-making skills, building confidence within themselves, which includes them moving at their own pace, discovering their own areas of interest and competencies, improving problemsolving, exerting self-control, following rules, learning to regulate emotions, making friends, getting along with others as equals, and experiencing joy (Ginsburg 2007; Gray 2011). Because of play, the child "ultimately engages fully in the passions they wish to pursue" (Ginsburg 2007, 183).

For children with impairments, concerns by adults for safety and a desire for "normal" often were found to interfere with the appreciation of play as an important way for children to learn. Ultimately, the creation of rules restricting child-driven play was found to limit some of the benefits of play and, in particular, those that developed creativity, leadership, and group skills (Ginsburg 2007). The parents of impaired children were able to acknowledge their overprotectiveness and the consequent limitation of the child's independence; however, largely they were unable to change and their stress was associated with further decreased participation 
(Anaby et al. 2013). This suggests that providing surveillance might be a solution to improve safety and provide reassurance for the children while they access to outdoor play learning environments.

Bottom-up, child-centered education can often provide opportunities for learning that topdown strategies cannot address. "Even a formal structured physical education class may not offer the same benefit as free-play recess" (Ginsburg 2007, 184). Studies found that children exert more motor and locomotor behaviors in free play in a playground than in physical education spaces (Barbour 1999). Natural environments were positively related to recreational activities among children with physical impairments (Anaby et al. 2013). The outdoor environment offers natural elements; "sticks, rocks, flowers, soil, water, etc., are explored with curiosity and drive to learn, as they offer countless possibilities to play" (Bento and Dias 2017). The natural landscape hereby provides affordances that encourage endless play potential with objects or places seen from the child's view point (Hendricks 2011).

The physical layout of the playground and design elements such as spatial density, clear circuits for movement, and a high lookout tower were found to increase play activities of children with autism (Anaby et al. 2013). Research also found that "equipment, materials and spatial delineation in outdoor learning environments influence children's physical and social skill development...each playground promotes or constrains the physical involvement and peer interactions of children with varying levels of physical competence" (Barbour 1999, 94). Finally the presence of peers in a playground plays an important role in the development of the child's perceptions and their impressions of classmates aiding in the development of their peer relationships (Barbour 1999). Social spaces that allow peer engagement are crucial for collaboration with younger impaired children.

The Fuji kindergarten school design by Tezuka Architects in Tokyo (Figure 1) is a leading school promoting self-directed play. It features an accessible oval roof with a circular open plan space in the center of the building, permitting play activities on the roof as well as views into internal activities. Physical boundaries combined with continuous space provide endless opportunities for play. The building caters for 640 children every year and operates during normal school hours. Architecturally, the building demonstrates "green building practice in forms that are legible for children, and [shows] how environmental sustainability can be incorporated in buildings in a way that has a positive impact on the children" (Scott 2010, 91). Sustainable practices were used as a part of the education program. The children "use pumps to get drinking water, a novelty that also leads to an understanding of its source" (Scott 2010,91). 


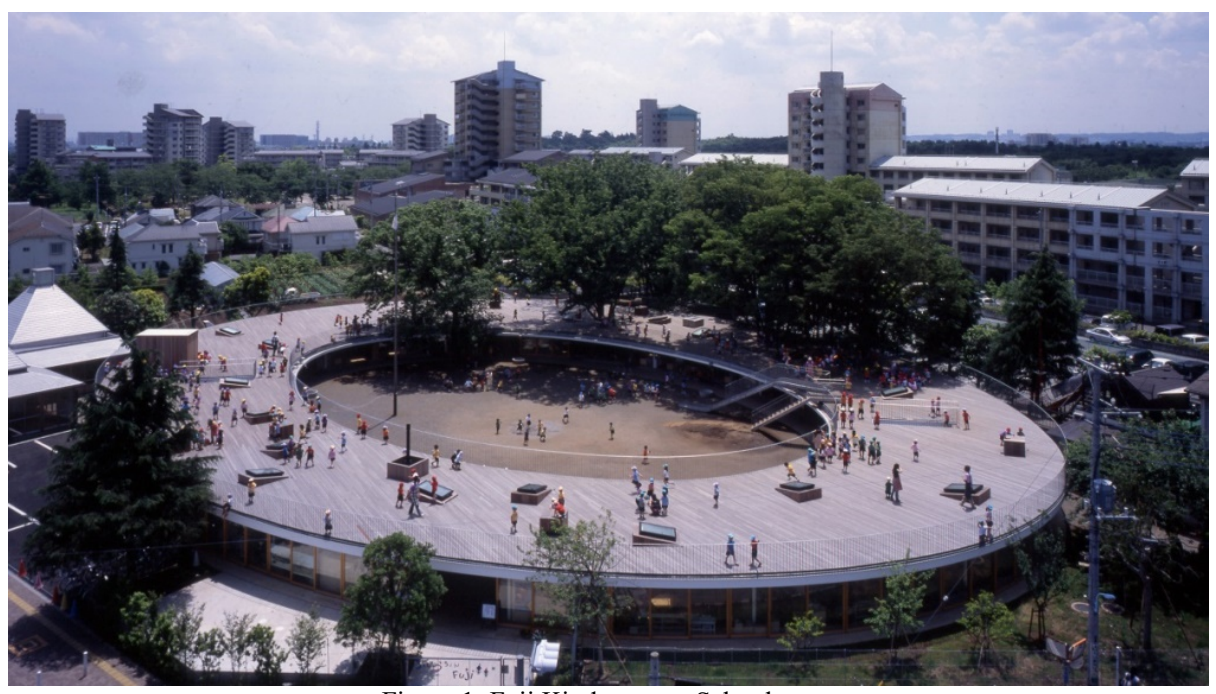

Figure 1: Fuji Kindergarten School

Source: Katsuhisa Kida ${ }^{2}$

A study found that children who went to Fuji Kindergarten School on average walked four thousand meters during school hours, and had much higher athletic abilities compared to other schools (Tezuka 2015). As the roof is accessible to both children and teachers, passive surveillance by adults can provide safety and security. Throughout the architecture, the building uses natural elements to be part of play activities, which offers restorative qualities to foster stress recovery and enhance learning in the individual. Studies found that direct contact with natural elements and views of nature could provide restoration of psychological equilibrium (Hartig and Evans 1993; Kaplan and Kaplan 1989).

\section{Sensory Integrated Play Activities}

Sensory integrated activities were found to be beneficial to motivate children with impairments. Over 80 percent of the nervous system involves processing or organizing sensory input (Ayres and Robbins 2005) and allows the brain to produce useful body responses and useful perceptions, emotions, and thoughts. When impairments compromise this ability, they restrict the sorting, ordering, and eventual combining of all sensory inputs together into a whole brain function (Ayres and Robbins 2005). A lack of sensory integration has been correlated with sensory integrative dysfunction problems, which include hyperactivity or distractibility, behavioral problems, speech and language delays, muscle tone and coordination problems, learning difficulties at school, and adolescence (Ayres and Robbins 2005).

At the Children's School by Maryann Thompson Architects in New York, "there is a visible water tank that captures water from the roof...the children fill their water cans from this tank to water the garden...the program was focused around recycling and growing a vegetable patch, but the most tangible expression of environmentalism was the materials used in the center's construction, whether recycled, renewable or just natural" (Scott 2010, 91) (Figure 2). Sustainable practices are not only valuable to the environment and educating children, there is a correlation between sustainable practices and encouraging more self-directed play.

\footnotetext{
${ }^{2}$ https://www.dezeen.com/2017/10/02/fuji-kindergarten-tokyo-tezuka-architects-oval-roof-deck-playground/
} 


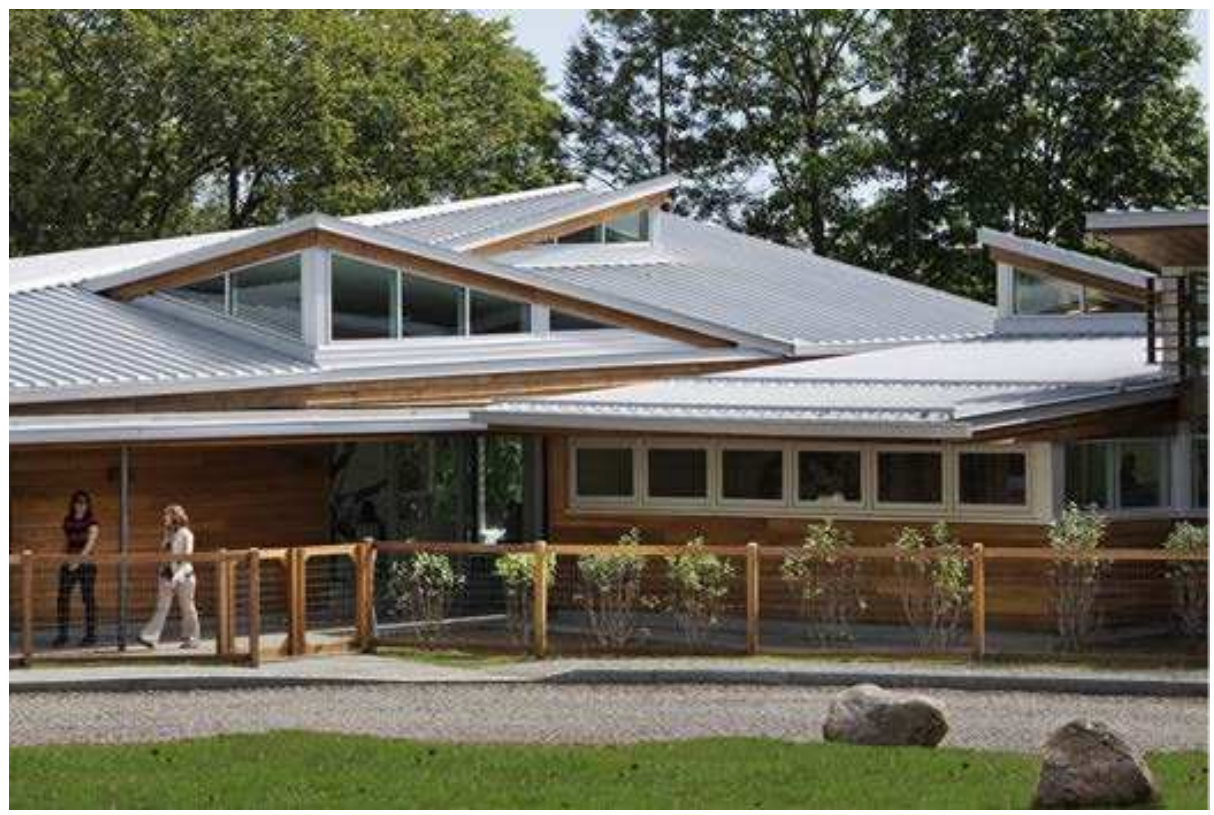

Figure 2: The Children's School in New York Source: $\mathrm{Choi}^{3}$

Sensory integration therapy involves tactile, proprioception, and vestibular therapy to address the impairments of the child. Although, this therapy cannot fully restore the impaired child, it can enable them to become more aware and acclimatize themselves to their own impairments. By implementing sensory integrated activities within school environment, increased confidence and self-awareness can develop which promotes mental well-being.

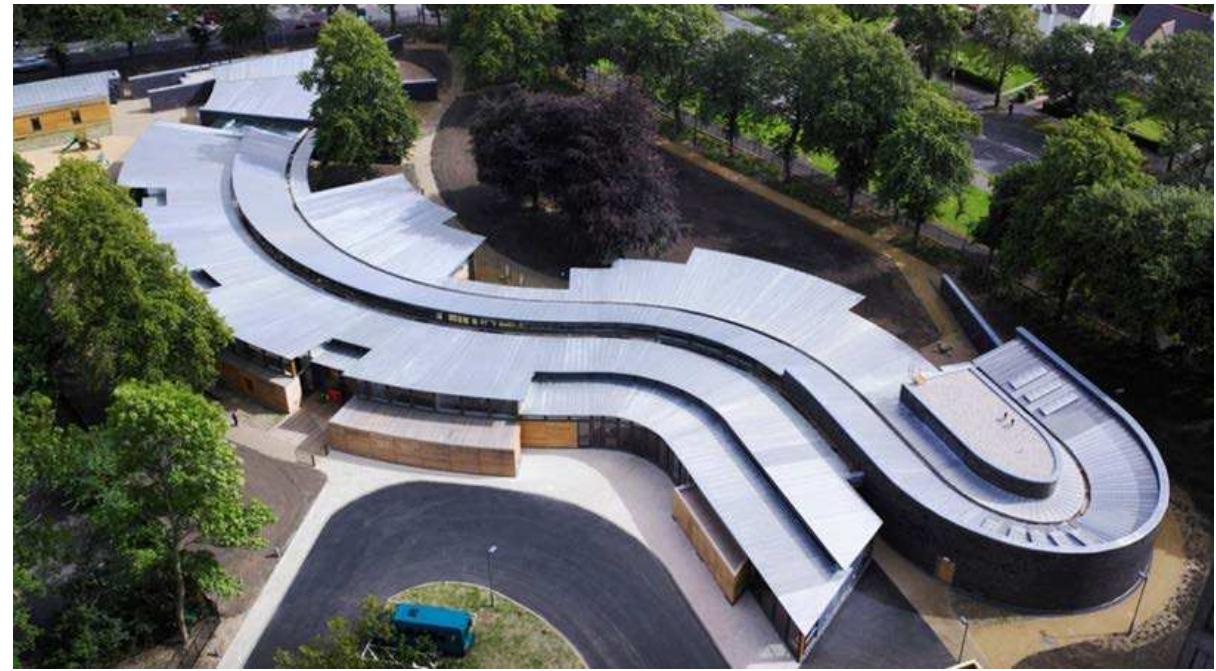

Figure 3: Hazelwood School

Source: Alan Dunlop Architect ${ }^{4}$

\footnotetext{
${ }^{3}$ https://www.childrensschool.org/

${ }^{4}$ https://www.arch2o.com/hazelwood-school-alan-dunlop-architect-limited/
} 
The Hazelwood School by Alan Dunlop Architects was designed for children with visual and hearing impairments, aged 2 to 18 . This school "delight[s] the senses, where taste, touch, smell and an awareness of surrounding could help promote a sense of independence and could act as sensory cues" (Dunlop 2011,2). The architect was determined to create "a school which would support the needs of the children and the aspirations of their parents, a place of safety and ambition that would free the teacher and inspire the child" (Dunlop 2011, 2). Through careful planning and consideration, the architecture allows those children to navigate easily through a tactile system on the wall and linear circulation throughout the building. As children with visual and hearing impairment are unable to see or hear, the architecture appeals to their other sense to orientate and encourage independence for the children.

\section{Community Use: Efficiency with Learning Environment}

Architects meekly followed their brief and were mainly concerned with formal aspects of the exterior without busying themselves with spatial opportunities that might lead to better education, and with the role they themselves might fulfil there. (Hertzberger 2008, 11)

Parents or caregivers of impaired children are at risk of suffering depression (Abi Daoud et al. 2004; Alschuler et al. 2012; Pangalila et al. 2015). Parental and peer support in a school environment could also foster social participation and friendship development (Anaby et al. 2013). Research found that informal caregiving for children with impairments had beneficial spiritual impact for caregivers (Marshall et al. 2003). Other studies suggested that community support could promote caregiver health, which might reduce the forced decisions to manage their children with impairments at home (Murphy et al. 2007). Participation in community-based leisure activities could also develop the quality of life within the community and promote health for children (Anaby et al. 2013). Cultural orientation and family recreational preferences were found to also have a direct correlation to the intensity of leisure participation (Anaby et al. 2013). Hence, an architectural program needs to include community spaces that can promote active engagement and longer-lasting participation for both caregivers and children, which in turn will improve the quality of life, and physical and mental well-being.

In all three case studies, children from families with lower incomes were present. Lower family income and parental education level have a direct impact towards lower participation levels in children (Bult et al. 2011). The level of stress is higher within lower income families. Fostering stress recovery strategies could be highly beneficial for children with impairments. Potential interventions may also be needed such as support groups, activities for parents outside the family, and ensuring access to mental health professionals. Accommodating these strategies could be ideal for fostering stress recovery in order to reduce the progressiveness nature of some of the impairments for children with impairments.

\section{Reducing Stress: Architectural Strategies}

When environmental demands and human resources are not met, stress is often experienced by the user (Evans 1984). A study found that stimulation, coherence, affordances, control, and restorative practices reduce stress within the built environment (Evans and McCoy 1998). The study primarily focused on how the building elements and building form influenced the occupant's stress levels within a space. It emphasized the design strategies for internal circulation spaces for occupants to navigate and articulated the program and activities in a more succinct manner. To prevent stress, the following strategies have been recommended: 
Table 2: Stress Recovery Strategies

\begin{tabular}{|c|c|c|c|}
\hline $\begin{array}{l}\text { Stress } \\
\text { Recovery } \\
\text { Strategy }\end{array}$ & Description & Implications & $\begin{array}{l}\text { Architectural } \\
\text { Consideration }\end{array}$ \\
\hline Stimulation & $\begin{array}{l}\text { Amount of } \\
\text { information within } \\
\text { a setting that can } \\
\text { have a negative } \\
\text { and positive } \\
\text { impact on the } \\
\text { human user }\end{array}$ & $\begin{array}{l}\text { Under stimulation can lead } \\
\text { user to boredom or sensory } \\
\text { deprivation. } \\
\text { Overstimulation cause } \\
\text { distraction and interfered } \\
\text { with cognitive processes } \\
\text { that affect concentration }\end{array}$ & $\begin{array}{l}\text { Spatial Layout } \\
\text { Proximity to circulation } \\
\text { Sense of surroundings } \\
\text { Internal space stimulation } \\
\text { Lighting } \\
\text { Acoustics } \\
\text { Adjacencies } \\
\text { Mystery }\end{array}$ \\
\hline Coherence & $\begin{array}{l}\text { Clarity of building } \\
\text { elements and } \\
\text { comprehensive } \\
\text { forms within the } \\
\text { built environment }\end{array}$ & $\begin{array}{l}\text { Ease of direction within a } \\
\text { space. Changes or } \\
\text { disruptions in physical } \\
\text { surroundings make } \\
\text { predictions difficult and } \\
\text { result in increasing stress } \\
\text { for the user. }\end{array}$ & $\begin{array}{l}\text { Building Element } \\
\text { Building Form / Geometry } \\
\text { Barriers } \\
\text { Organization } \\
\text { Thematic Structure } \\
\text { Signage } \\
\text { Predictability } \\
\text { Pathway configuration }\end{array}$ \\
\hline Affordance & $\begin{array}{l}\text { Designing interior } \\
\text { spaces to promote } \\
\text { an understanding } \\
\text { of the functions } \\
\text { that they provide } \\
\text { us. }\end{array}$ & $\begin{array}{l}\text { Ambiguity and } \\
\text { misinformation lead to } \\
\text { frustration, annoyance, } \\
\text { hostility and helplessness }\end{array}$ & $\begin{array}{l}\text { Information systems } \\
\text { Corners } \\
\text { Entryways } \\
\text { Stairs } \\
\text { Sudden perceptual changes } \\
\text { Feedback }\end{array}$ \\
\hline Control & $\begin{array}{l}\text { A sense of control } \\
\text { in an environment } \\
\text { is necessary to } \\
\text { allow users to } \\
\text { direct the activity. }\end{array}$ & $\begin{array}{l}\text { Lack of control over the } \\
\text { space may not address the } \\
\text { individual's needs to } \\
\text { effectively interact in the } \\
\text { internal space. }\end{array}$ & $\begin{array}{l}\text { Spatial Arrangement } \\
\text { Spatial Hierarchy } \\
\text { Spatial Resources } \\
\text { Climatic and lighting } \\
\text { control } \\
\text { Uniformity of materials and } \\
\text { furnishings } \\
\text { Privacy } \\
\text { Responsiveness / Adaptable } \\
\text { spaces } \\
\text { Symbolism } \\
\text { Focal Point }\end{array}$ \\
\hline Restorative & $\begin{array}{l}\text { Design elements } \\
\text { to function } \\
\text { therapeutically to } \\
\text { reduce stress } \\
\text { levels and } \\
\text { cognitive fatigue }\end{array}$ & $\begin{array}{l}\text { Lack of restorative } \\
\text { qualities could induce } \\
\text { cognitive fatigue and } \\
\text { stress }\end{array}$ & $\begin{array}{l}\text { Exposure to nature } \\
\text { Retreat / Solitude } \\
\text { Fascination } \\
\text { Privacy } \\
\text { Minimal distraction }\end{array}$ \\
\hline
\end{tabular}

Play promotes children to develop intrinsic interests and competencies, learn to make decisions, solve problems, exert self-control, follow rules, regulate emotions, make friends, and get along with others (Gray 2011). However, one study found that parents and teachers did not regard play as important in young children (Rothlein and Brett 1987). The stigma associated with the safety and security of impaired children today hinders the child's freedom of play. Architecture can be only a platform toward facilitating play for children. There may be a need to 
change the model of education toward more self-directed play or learning for children. This could create a positive impact for the psychological development of the child and make learning more engaging through self-direction, allowing the child to develop skills, interests, and aspirations.

\section{Conclusions}

Through a multi-disciplinary literature review and analysis of case studies, the potential to design a quality learning environment for children with impairments has been explored. Children with impairments significantly benefit from sustainable practices that facilitate outdoor learning environments. Schools that implement sensory integrated activities, provide for community engagement and use, and reduce stress for caregivers and students are the most successful.

Advice on the design of environments that addresses issues associated with impairment, the severity of impairment, and combinations of impairments is lacking in architectural literature. Many mainstream school environments were unable to accommodate the severity and variation of impairment needs in their school designs. There is a need for design testing across a range of impairments to understand the relationships and highlight the importance of specific architectural elements for each impairment or combination of impairments.

Architecture has the capacity to affect health through environmental quality. Designed environments that facilitate play and sensory integrated activities can allow children with impairments to be more acclimatized to their impairments, and thereby improve their independence and wellbeing, as well as reduce healthcare demands and expenses. This article has discussed design criteria that could improve the experience for children with impairments and increase their participation in primary education, while protecting their safety and welfare.

A community-centered approach can also improve the quality of life for the caregivers, which has a direct correlation to the quality of care the child is receiving. Implementing playlearning spaces to encourage self-directed play and unifying a play approach while combining the school with the community center can create a broader spectrum of opportunity. Merging community with learning can promote inclusiveness and address negative views, reducing the stigmatization related to play by impaired children in school designs and outdoor learning environments. Restoring participation of children with impairments in the school system can benefit their education and allow them to grow into psychologically healthy and emotionally competent adults; but perhaps more significantly it can also benefit caregivers through the reduction of stress and stigma and benefit other children and the wider community by creating a more inclusive environment. 


\section{REFERENCES}

Abdel-Maksoud, Asmaa Hamed. 2016. "The Role of Universal Design in Virtual Deaf Schools: Case Study Deaf Space.” International Design Journal 26 (63): 1-16. https://doi.org $10.12816 / 0036499$.

Abi Daoud, Marie S., Joseph M. Dooley, and Kevin E. Gordon. 2004. "Depression in Parents of Children with Duchenne Muscular Dystrophy." Pediatric Neurology 31 (1): 16-19. https://doi.org/10.1016/j.pediatrneurol.2004.01.011.

Alschuler, Kevin N., Mark P. Jensen, Mark C. Goetz, Amanda E. Smith, Aimee M. Verrall, and Ivan R. Molton. 2012. "Effects of Pain and Fatigue on Physical Functioning and Depression in Persons with Muscular Dystrophy." Disability and Health Journal 5 (4): 277-83. https://doi.org/10.1016/j.dhjo.2012.07.002.

Anaby, Dana, Carri Hand, Laura Bradley, Briano DiRezze, Mary Forhan, Anthony DiGiacomo, and Mary Law. 2013. "The Effect of the Environment on Participation of Children and Youth with Disabilities: a Scoping Review." Disability and Rehabilitation 35 (19): 1589-98. https://doi.org/10.3109/09638288.2012.748840.

Ayres, A Jean, and Jeff Robbins. 2005. Sensory Integration and the Child: Understanding Hidden Sensory Challenges: Los Angeles: Western Psychological Services.

Barbour, Ann C. 1999. "The Impact of Playground Design on the Play Behaviors of Children with Differing Levels of Physical Competence.” Early Childhood Research Quarterly 14 (1): 75-98. https://doi.org/10.1016/S0885-2006(99)80007-6.

Bento, Gabriela, and Gisela Dias. 2017. "The Importance of Outdoor Play for Young Children's Healthy Development." Porto Biomedical Journal 2 (5): 157-60. https://doi.org/10.1016/j.pbj.2017.03.003.

Bult, M. K., O. Verschuren, M. J. Jongmans, E. Lindeman, and M. Ketelaar. 2011. "What Influences Participation in Leisure Activities of Children and Youth with Physical Disabilities? A Systematic Review." Research in Developmental Disabilities 32 (5): 1521-29. https://doi.org/10.1016/j.ridd.2011.01.045.

Case-Smith, J., and Teresa Bryan. 1999. "The Effects of Occupational Therapy with Sensory Integration Emphasis on Preschool-age Children with Autism". The American Journal of Occupational Therapy 53 (5): 489-97. https:// doi:10.5014/ajot.53.5.489.

Curran, A. L., P. M. Sharples, C. White, and Martin Knapp. 2001. "Time Costs of Caring for Children with Severe Disabilities Compared with Caring for Children without Disabilities." Development Medicine and Child Neurology 43 (8): 529-33. https://doi.org/10.1017/S0012162201000962.

Dunlop, Alan. 2011. Hazelwood School Sketchbook. Aberfoyle: Alan Dunlop Architect. http://www.alandunloparchitects.com/wp-content/uploads/2011/03/Hazelwood-

Sketchbook.pdf./

Evans, Gary W. 1984. Environmental Stress. London: Cambridge University Press.

Evans, Gary W., and Janetta Mitchell McCoy. 1998. "When Buildings Don't Work: the Role of Architecture in Human Health." Journal of Environmental Psychology 18 (1): 85-94. https://doi.org/10.1006/jevp.1998.0089.

Ginsburg, Kenneth R. 2007. "The Importance of Play in Promoting Healthy Child Development and Maintaining Strong Parent-child Bonds." Pediatrics 119 (1): 182-91. https://doi.org/10.1542/peds.2006-2697.

Gray, Peter. 2011. "The Decline of Play and the Rise of Psychopathology in Children and Adolescents." American Journal of Play 3 (4): 443-63.

Hartig, Terry, and Gary W Evans. 1993. "Psychological Foundations of Nature Experience." Advances in Psychology 96: 427-27. https://doi.org/10.1016/S0166-4115(08)60053-9.

Hendricks, Barbara E. 2011. Designing for Play. London: Routledge. https://doi.org/10.4324/9781315258102. 
Hertzberger, Herman. 2008. Space and Learning: Lessons in Architecture 3. Rotterdam: 010 Publishers.

Imrie, Rob. 2003. "Housing Quality and the Provision of Accessible Homes." Housing Studies 18 (3): 387-408. https://doi.org/10.1080/02673030304240.

Imrie, Rob, and Peter Hall. 2003. Inclusive Design: Designing and Developing Accessible Environments. London: Taylor \& Francis. https://doi.org/10.4324/9780203362501.

Imrie, Rob, and Marion Kumar. 1998. "Focusing on Disability and Access in the Built Environment." Disability \& Society $13 \quad$ (3): $\quad 357-74$. https://doi.org/10.1080/09687599826687.

Kaplan, Rachel, and Stephen Kaplan. 1989. The Experience of Nature: A Psychological Perspective. New York: Cambridge University Press.

Kershaw, Chelsea, Jacqueline McIntosh, Bruno Marques, Jon Cornwall, Lee Stoner, and Phil Wood. 2017. "A Potential Role for Outdoor, Interactive Spaces as a Healthcare Intervention for Older Persons." Perspectives in Public Health 137 (4): 212-13. https://doi.org/10.1177\%2F1757913917709402.

Law, Mary. 2002. "Participation in the Occupations of Everyday Life." American Journal of Occupational Therapy 56 (6): 640-49. https://doi:10.5014/ajot.56.6.640.

Leonard, Barbara J., Ann Louise Johnson, and Janny Dwyer Brust. 1993. "Caregivers of Children with Disabilities: a Comparison of Those Managing 'OK' and Those Needing More Help." Children's Health Care 22 (2): 93-105. https://doi.org/10.1207/s15326888chc2202_2.

Mah, Jean K., Jennifer E. Thannhauser, Hanna Kolski, and Deborah Dewey. 2008. "Parental Stress and Quality of Life in Children with Neuromuscular Disease." Pediatric Neurology 39 (2): 102-07. https://doi.org/10.1016/j.pediatrneurol.2008.04.011.

Marques, Bruno, Jacqueline McIntosh, and Chelsea Kershaw. 2019. "Healing Spaces: Improving Health and Wellbeing for the Elderly Through Therapeutic Landscape Design." International Journal of Arts and Humanities 3 (2): 20-34.

Marshall, Elaine Sorensen, Susanne Frost Olsen, Barbara L Mandleco, Tina Taylor Dyches, Keith W Allred, and Nancy Sansom. 2003. "This is a Spiritual Experience: Perspectives of Latter-Day Saint Families Living with a Child with Disabilities." Qualitative Health Research 13 (1): 57-76. https://doi.org/10.1177\%2F1049732302239411.

Murphy, Nancy A., and Paul S. Carbone, 2008. "Promoting the Participation of Children with Disabilities in Sports, Recreation, and Physical Activities." Pediatrics 121 (5): 1057-61. https://doi.org/10.1542/peds.2008-0566.

Murphy, Nancy A., B. Christian, D. A. Caplin, and P. C. Young. 2007. "The Health of Caregivers for Children with Disabilities: Caregiver Perspectives." Child: Care, Health and Development 33 (2): 180-87. https://doi.org/10.1111/j.1365-2214.2006.00644.x.

National Scientific Council on Developing Children. 2011. Children's Emotional Development Is Built into the Architecture of Their Brains. Cambridge, MA: Harvard University. http://www.developingchild.net.

Pangalila, Robert F., Geertrudis A. van den Bos, Bart Bartels, Michael Bergen, Henk J. Stam, and Marij E. Roebroeck. 2015. "Prevalence of Fatigue, Pain, and Affective Disorders in Adults With Duchenne Muscular Dystrophy and Their Associations With Quality of Life." Archives of Physical Medicine and Rehabilitation 96 (7): 1242-47. https://doi.org/10.1016/j.apmr.2015.02.012.

Rothlein, Liz, and Arlene Brett. 1987. "Children's, Teachers; and Parents' Perceptions of Play." Early Childhood Research Quarterly 2 (1): 45-53. https://doi.org/10.1016/08852006(87)90012-3.

Scott, Sarah. 2010. Architecture for Children. Victoria: Australian Council for Educational Research. 
Sorani-Villanueva, Sandra, Susan McMahon, Ronald Crouch, and Christopher Keys. 2014. "School Problems and Solutions for Students with Disabilities: A Qualitative Examination." Journal of Prevention \& Intervention in the Community 42 (1): 58-71. https://doi.org/10.1080/10852352.2014.855060.

Tezuka, Takaharu. 2015. “The Best Kindergarten You've Ever Seen.” TED, Kyoto. Accessed https://www.ted.com/talks/takaharu_tezuka_the_best_kindergarten_you_ve_ever_seen? anguage $=$ en.

UNICEF. 2013. Take Us Seriously! Engaging Children with Disabilities in Decisions Affecting their Lives. New York: United Nations Children's Fund. https://www.unicef.org/disabilities/files/Take_Us_Seriously.pdf.

World Health Organization (WHO). 2011. World Report on Disability. Malta: World Health Organization and The World Bank. https://www.who.int/disabilities/world_report/2011/report.pdf.

\section{ABOUT THE AUTHORS}

Jacqueline McIntosh: Senior Lecturer, School of Architecture, Victoria University of Wellington, New Zealand

Bruno Marques: Senior Lecturer, School of Architecture, Victoria University of Wellington, Wellington, New Zealand

Joelle Lim: Postgraduate Student, School of Architecture, Victoria University of Wellington, Wellington, New Zealand 
The International Journal of Design in Society is one of six thematically focused journals in the family of journals that support the Design Principles and Practices Research Network -its journals, book imprint, conference, and online community. It is a section of Design Principles and Practices: An International Journal.

The International Journal of Design in Society interrogates the social sources and social effects of design. Focal points of interest include design policy, the human impacts of design, design values, and design as business.

As well as papers of a traditional scholarly type, this journal invites case studies that take the form of presentations of practice-including documentation of socially-engaged design practices and exegeses analyzing the effects of those practices.

The International Journal of Design in Society

is a peer-reviewed, scholarly journal. 